\title{
Spontaneous release of epiretinal membrane in a young weight-lifting athlete by presumed central rupture and centrifugal pull
}

This article was published in the following Dove Press journal:

Clinical Ophthalmology

13 November 2014

Number of times this article has been viewed

\author{
Ahmad M Mansour ${ }^{1,2}$ \\ Hana A Mansour ${ }^{3}$ \\ J Fernando Arevalo ${ }^{4,5}$ \\ 'Department of Ophthalmology, \\ Rafic Hariri University Hospital, \\ Beirut, Lebanon; ${ }^{2}$ Department \\ of Ophthalmology, American \\ University of Beirut, Beirut, Lebanon; \\ ${ }^{3}$ Department of Biology, American \\ University of Beirut, Beirut, Lebanon; \\ ${ }^{4}$ Retina Department, The King Khaled \\ Eye Specialist Hospital, Riyadh, \\ Kingdom of Saudi Arabia; ${ }^{5}$ Retina \\ Department, Wilmer Eye Institute, \\ The Johns Hopkins University, \\ Baltimore, MD, USA
}

\begin{abstract}
This patient presented for surgery at the age of 32 years, 14 months after his initial complaint of metamorphopsia and visual loss in the right eye. Past tests demonstrated a whitish epiretinal membrane (ERM) with translucent stress lines over a thickened macula. Visual acuity was found on last presentation to be normal with minimal alteration on Amsler grid testing. A torn ERM was found in the center with left-over ERM temporally and rolled-over ERM nasally at the site of the epicenter with no posterior vitreous detachment. Visual recovery occurred gradually over several days 2 months prior to presentation apparently following heavy weight-lifting with a sensation of severe eye pressure. Sequential funduscopy and optical coherence tomography scans demonstrated the peeling of an ERM accompanied by normalization of foveal thickness. Valsalva maneuver had put excessive tension on ERM which tore in its center at the weakest line with gradual contraction of the ERM away from the fovea towards the peripapillary area. This is a new mechanism of self-separation of ERM induced by Valsalva. ERM in young subjects is subject to rupture and subsequent separation by tangential traction. There are three mechanisms for spontaneous separation of ERM: 1) posterior vitreous detachment with pulling of ERM by detaching vitreous (most common in adults); 2) the contracting forces of the immature ERM become stronger than its adhesions to the retina resulting in slow tangential traction on the edges of the ERM and gradual separation from the edges towards the center (remodeling common in youngsters); and 3) acute tearing of ERM at its weakest central point and retraction of part of the membrane towards the epicenter (current case report).
\end{abstract}

Keywords: valsalva maneuver, posterior vitreous detachment

\section{Introduction}

Epiretinal membranes (ERMs) are characterized by wrinkling of the macular surface from cell proliferation. Most commonly ERMs are noted in adults above the age of 50 years in association with posterior vitreous detachment (PVD), laser photocoagulation, or after retinal detachment repair. A majority of ERM in adults is of the cellophane macular reflex type referring to the thin transparent variety. ${ }^{1}$ ERM in children and young adults is uncommon, because a PVD is uncommon in very young subjects. Ocular trauma, pars planitis, ocular toxocariasis, ocular toxoplasmosis, combined hamartoma of the retina and retinal pigment epithelium, and Coats' disease are leading causes of secondary ERM in children. The prevalence of ERM in subjects less than 20 years of age is around 1 in 20,000. ${ }^{1}$ A majority of ERM in young subjects is of the thick white contractile variety having strong adherence to retinal vessels. ${ }^{2,3}$ Myofibroblasts, myoblastic differentiation of retinal pigment epithelial cells and fibrous astrocytes, as well as new collagen formation are more common in ERM of young subjects than in ERM in older subjects. ${ }^{4}$ We report a young adult with ERM that underwent spontaneous
Correspondence: J Fernando Arevalo Vitreoretinal Division, The King Khaled Eye Specialist Hospital, Al-Oruba Street, PO Box 7|9I, Riyadh I|462, Kingdom of Saudi Arabia

Tel +966 I| 482 I234 Ext 3860

Fax+966 II 482 I234 Ext 3727

Email arevalojf@jhmi.edu 


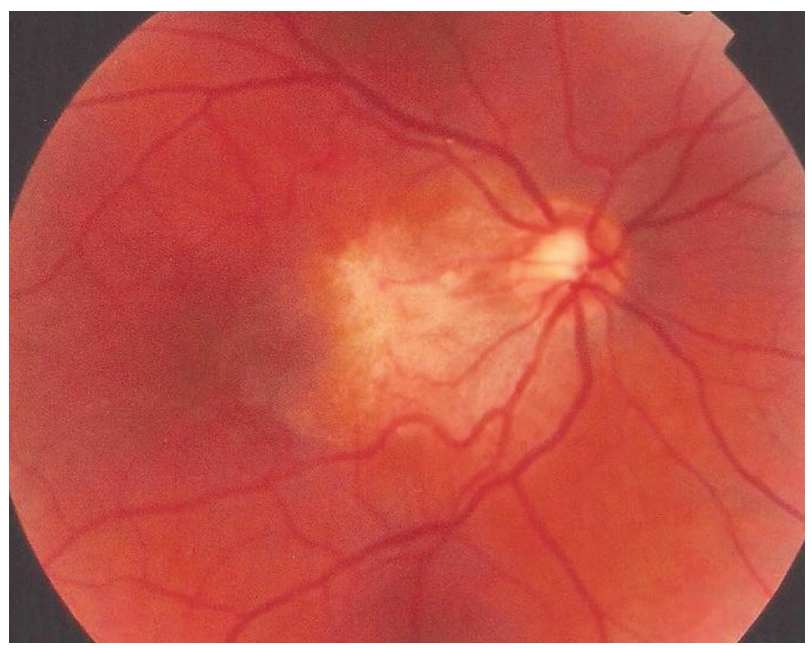

Figure I Fundus photograph 18 months before presentation.

Notes: The opaque ERM bridges between multiple fixation points on the retinal surface, obscuring the view to the macula. Note that traction lines correspond with wrinkling of the ILM.

Abbreviations: ERM, epiretinal membrane; ILM, internal limiting membrane.

release in a peculiar way (ERM tearing centrally) apparently following Valsalva maneuver.

\section{Case report}

This 32 year-old healthy man complained of visual loss in the right eye 14 months prior to presentation and he was referred for surgical peeling of an ERM (Figures 1-5) by two retina experts. Two months before presentation, he indulged in heavy weight-lifting and noted repeatedly severe eye

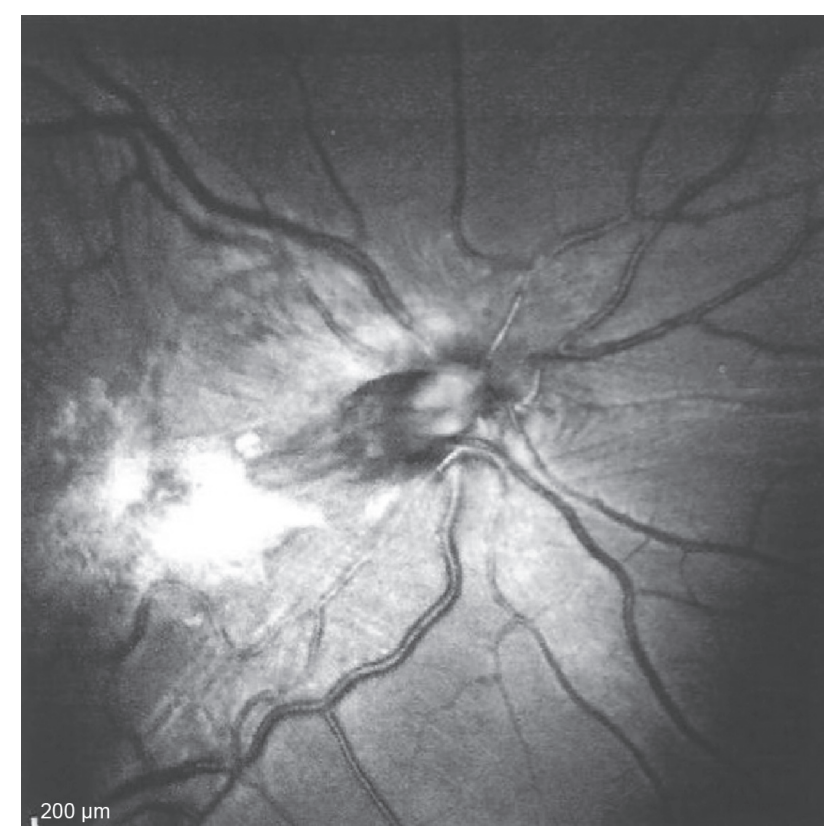

Figure 2 Red-free photograph of the right posterior pole.

Note: An opaque epiretinal membrane covers the macula resulting in superficial radial folds.

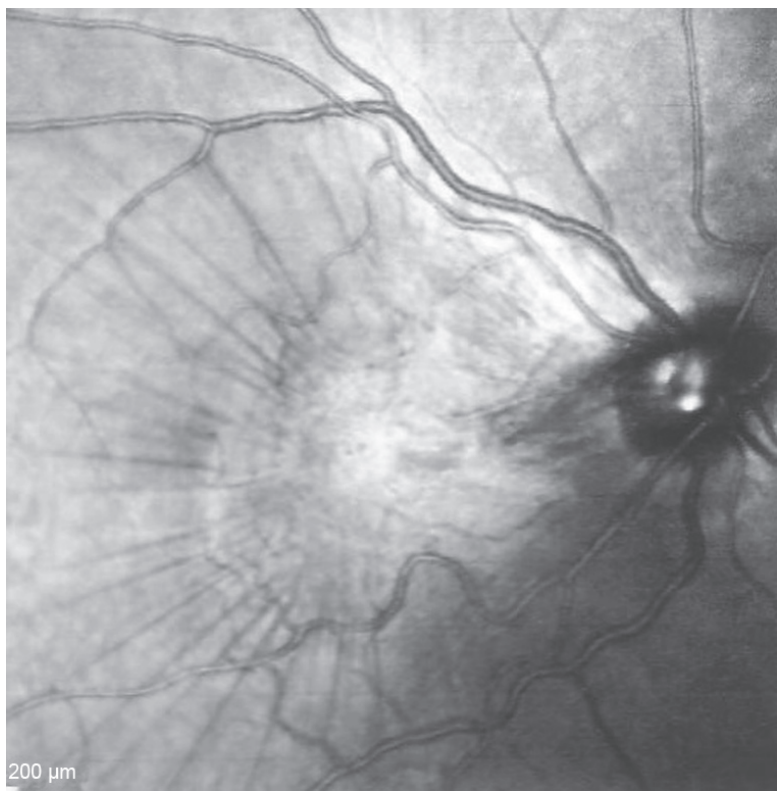

Figure 3 Infrared photograph of the right posterior pole.

Note: An opaque epiretinal membrane covers the macula with prominent traction exerted on the inner retinal surface in the form of superficial radial folds.

pressure during the exercise. Then he noted a gradual visual improvement in the right eye over several days. Two months later, ophthalmic exam revealed 6/6 uncorrected visual acuity with findings of a residual rolled-over ERM supranasal to the fovea (Figure 6). The patient denied ocular rubbing or previous ocular trauma. Amsler grid revealed mild distortion temporally. Past fundus photograph 1.5 years ago revealed a

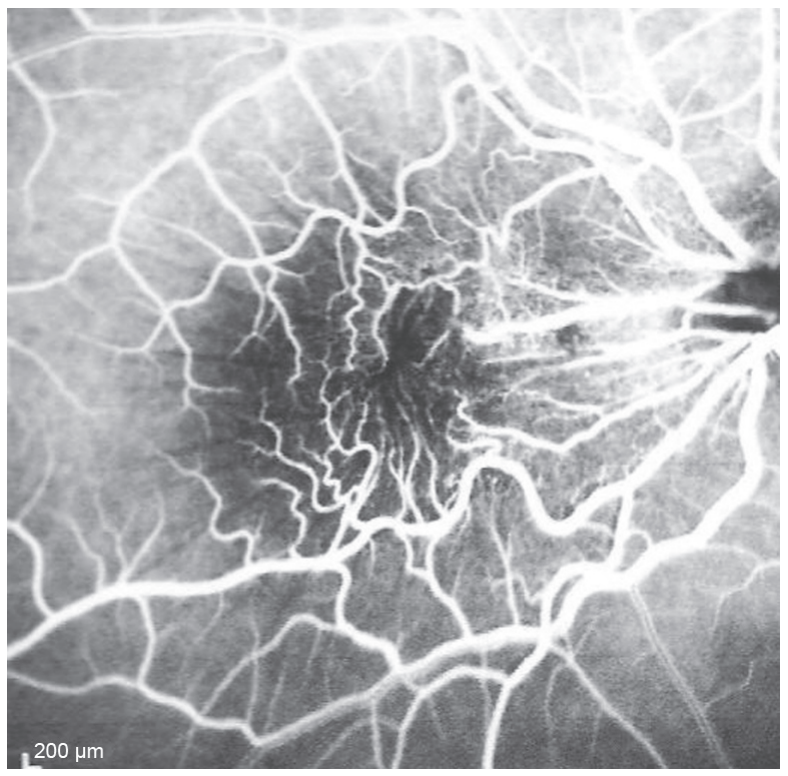

Figure 4 Arteriovenous phase of fluorescein angiography transit.

Notes: Visible retinal vessels at the posterior pole appear tortuous. The superior and inferior vessels appear narrowed and the perimacular vessels are pulled towards the epicenter with prominent retinal striae. 


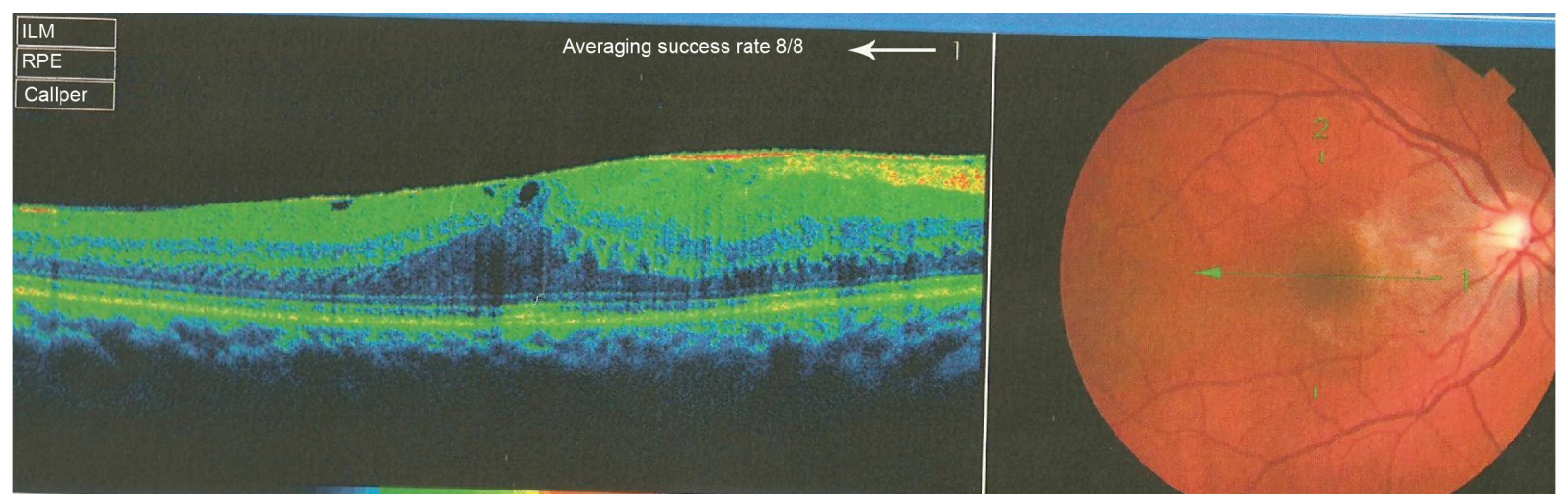

Figure 5 Optical coherence tomography done I year before presentation revealed a diffuse epiretinal membrane being thin temporal to the fovea and very thick nasal to the fovea (epicenter) with marked thickening of the central fovea.

dense macular gliosis with prominent radial stress line (best seen on infrared photography) throughout the posterior pole and centered around the thickest part of the membrane nasal to the disc (as noted by red-free photograph [Figure 2]). Intravenous fluorescein angiography done at the same time revealed obliteration of foveal avascular zone with tortuous macular capillaries and stretched out papillomacular vessels. Optical coherence tomography (OCT) done 1 year ago (Figure 5) revealed a diffuse ERM thin temporal to the fovea and very thick nasal to the fovea with marked thickening

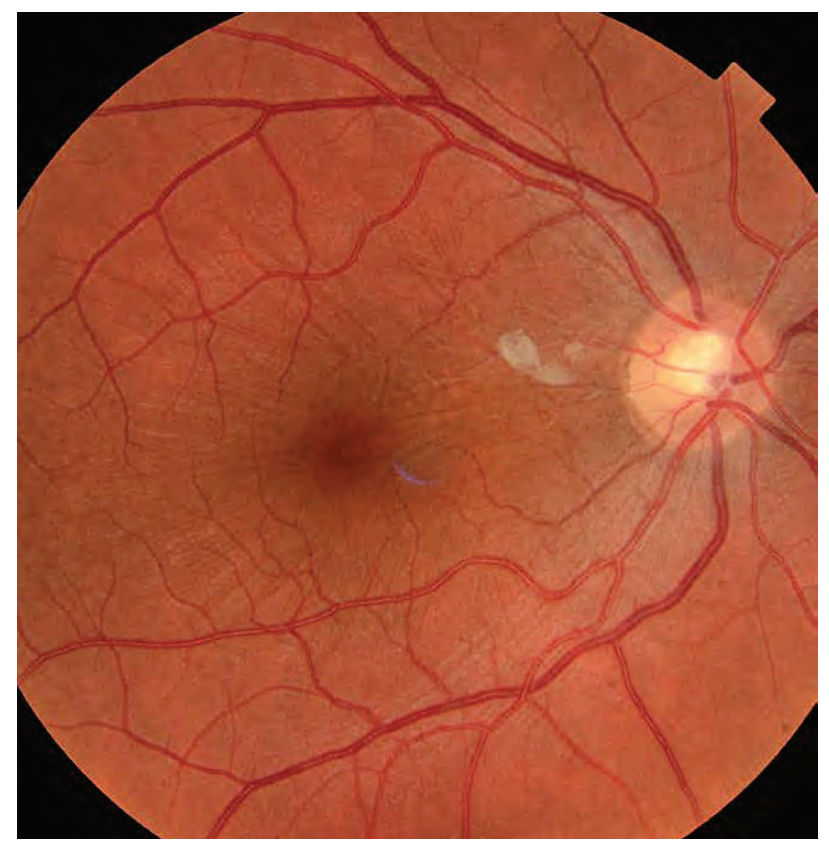

Figure 6 Fundus photograph of the right eye taken more than I year after the patient's initial presentation.

Notes: Epiretinal membrane (ERM) has spontaneously released and contracted nasally. Remnants of the ERM are still present as tiny, white, pre-retinal flakes at the superior-macular arcade. Traction on the fovea is now relieved and there is residual wrinkling of the internal limiting membrane. Note that the vessels in the macula region are no longer distorted compared with the previous pattern. of the central fovea. OCT upon presentation demonstrated central peeling of ERM (Figure 7) accompanied by normalization of central foveal thickness (Figure 8). ERM rupture could be noted with one edge ruptured temporally and the nasal edge rolling over (Figure 9). The thick nasal membrane rolled over itself denoting its elastic property. There was no PVD identified by OCT or by slit lamp fundus biomicroscopy with a 90 diopter lens.

\section{Discussion}

ERM in young subjects commonly causes both metamorphopsia and reduced visual acuity from reduced axoplasmic flow, abnormal hemodynamic microcirculation, light-filtering effect of ERM, and photoreceptor distortion by tangential traction..$^{5-7}$ Clinically, the superior and inferior vessels are narrowed while the perimacular vessels are pulled toward the epicenter with inner retinal striae. ERM in young people and children is rare and may be caused by congenital defects resulting from persistent adhesions of primary vitreous to the retina. ${ }^{7}$ The clinical and ultrastructural features of juvenile macular pucker reflect a more rapidly changing, contractile tissue ${ }^{4}$ compared with the usually more quiescent features in most cases involving older patients.

ERM is common in adults and rare in the young. However in adults, PVD can damage the internal limiting membrane, thereby permitting the migration of glial cells to the retinal surface. ${ }^{6,8}$ Alternate proposed hypothesis in adults is that an incomplete PVD provides the conditions suitable for membrane proliferation in the adhesion area between the vitreous and the retina. The cells involved in this process are retinal pigment epithelium metaplastic cells, glial cells (Muller cells and astrocytes), hyalocytes, ${ }^{9}$ endothelial cells, fibroblasts, myofibroblasts, monocytes, and macrophages. It appears that several growth factors ${ }^{10}$ (platelet-derived 


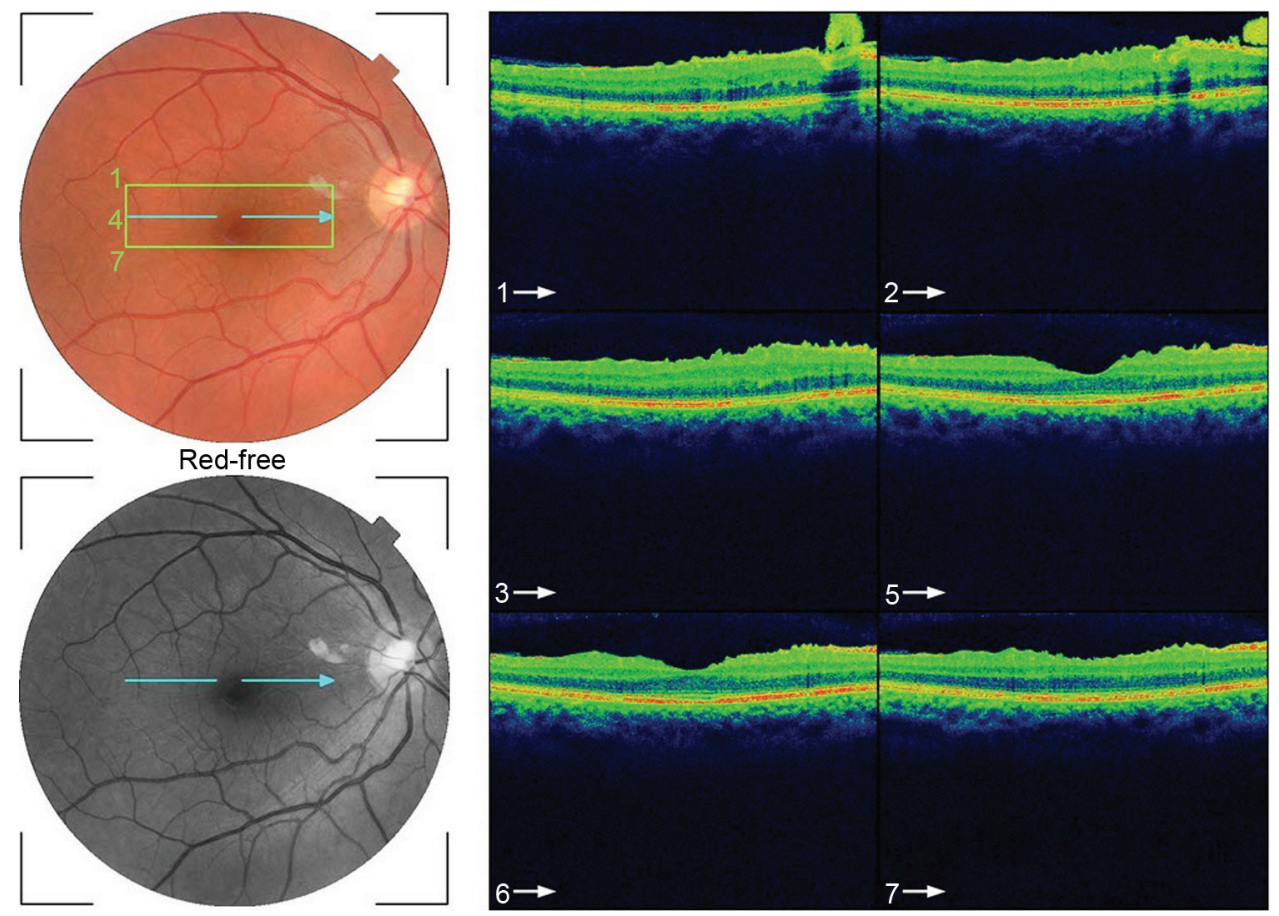

Figure 7 Serial horizontal optical coherence tomography scans demonstrate rupture of the epiretinal membrane (ERM) temporal to fovea with retraction of remaining ERM nasally and return of the normal foveal contour.

growth factor, tissue growth factor TGF betal and 2, fibroblast growth factor, vascular endothelial growth factor, nerve growth factor) could stimulate glial cells to transdifferentiate into myofibroblasts and stimulate myofibroblasts to turn on their contractile actions more so in young subjects. ${ }^{9-11}$ Moreover the role of plasminogen and metalloproteinases in contraction of ERM has been raised. ${ }^{12,13}$ Spontaneous release of ERM is a rare event but is known to occur in adults and is related to the occurrence of an acute PVD that simultaneously releases the attachment between the retina and ERM (Figures 10, 11). Separation or peeling of ERM in young subjects is quite rare. ${ }^{14-30}$ It may occur spontaneously by development of a $\mathrm{PVD},{ }^{23}$ or shortly after panretinal photocoagulation or Nd:YAG (neodymium-doped yttrium aluminum garnet) posterior capsulotomy ${ }^{27}$ Meyer et al ${ }^{15}$ presented six cases of spontaneous gradual "remodeling" with release of ERM in young subjects. They hypothesized that when the contracting forces of the immature ERM are stronger than its adhesions to the retina, the membrane may separate spontaneously. Only one of six cases had PVD ${ }^{15}$ and

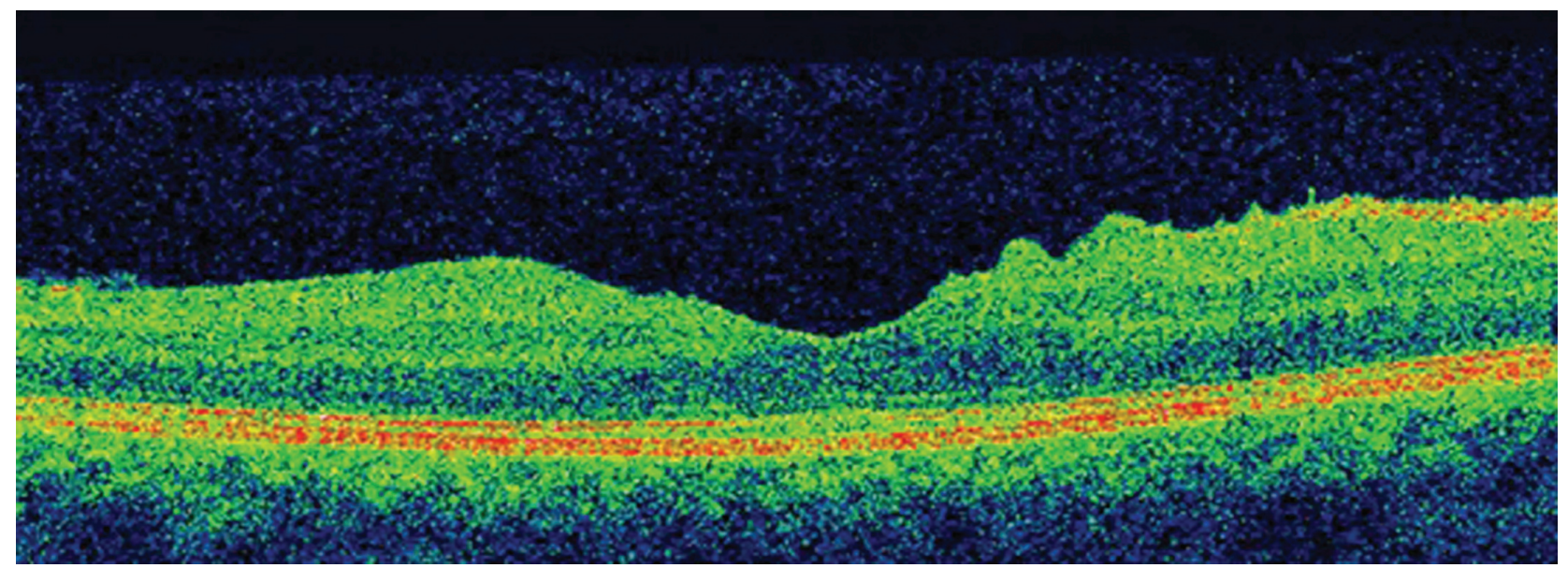

Figure 8 Close up view of horizontal optical coherence tomography scan showing normal foveal contour. 


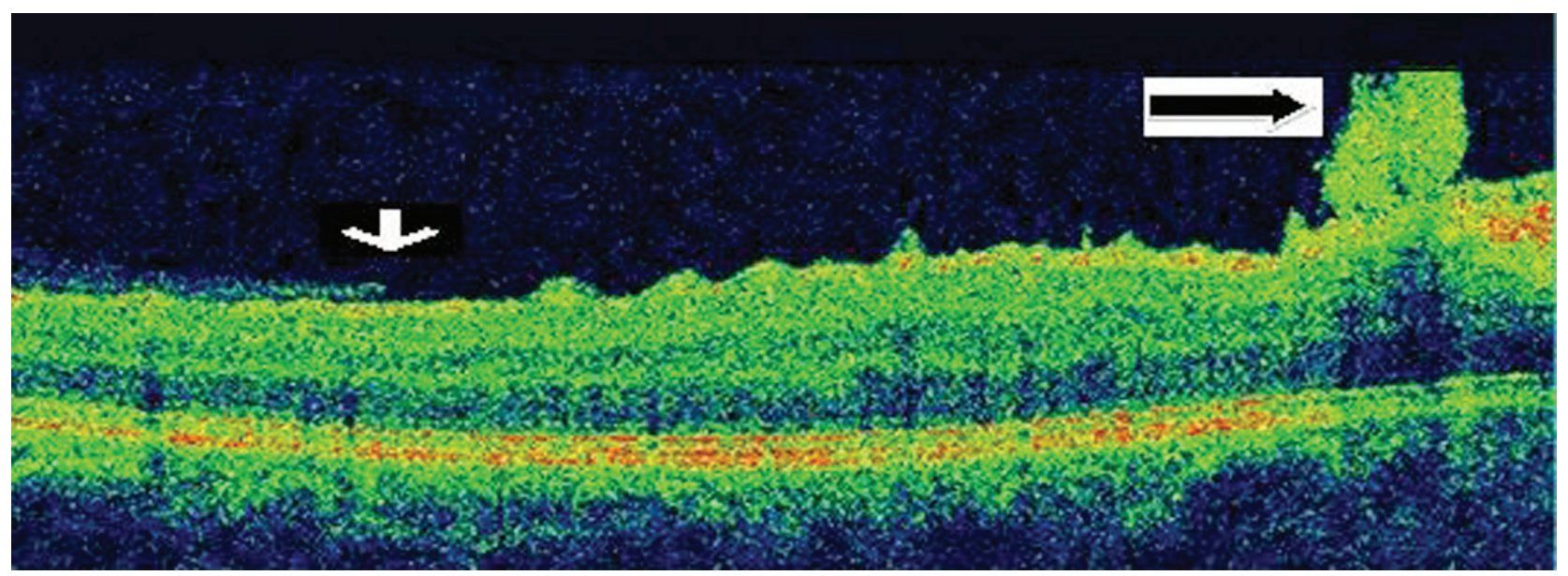

Figure 9 Close up view of horizontal optical coherence tomography scan just above the foveal plane showing edge of ruptured epiretinal membrane (ERM) (white arrow) temporally and rolled-over hyper-reflective ERM nasally (black arrow).

one case with prior PVD also had release of ERM. ${ }^{16}$ ERM release was more common in eyes with PVD: $:^{23}$ in a study of 1,248 consecutive eyes with idiopathic ERM followed-up for around 3 years, ERM self-separation occurred in 37 eyes (3.0\%), with 16 of 1,091 eyes with pre-existing PVD $(1.5 \%)$ and 21 of 157 eyes without pre-existing PVD (13.4\%). ${ }^{23} \mathrm{~A}$ higher rate of spontaneous separation was reported in Japan: Nomoto et $\mathrm{al}^{24}$ detected five patients with spontaneous separation of ERM among 92 patients with idiopathic ERM.

Three mechanisms (Figures 10-15) are proposed for spontaneous ERM separation including the two previously described ones: PVD (Figure 11), remodeling (contraction of myofibroblast) (Figures 12, 13), and rupture of weakest line by lifting heavy objects (Valsalva) (Figures 14, 15). Head-down position combined with weight-lifting (Table 1) and mouth closure lead to high intraocular pressure (IOP) (rise can reach

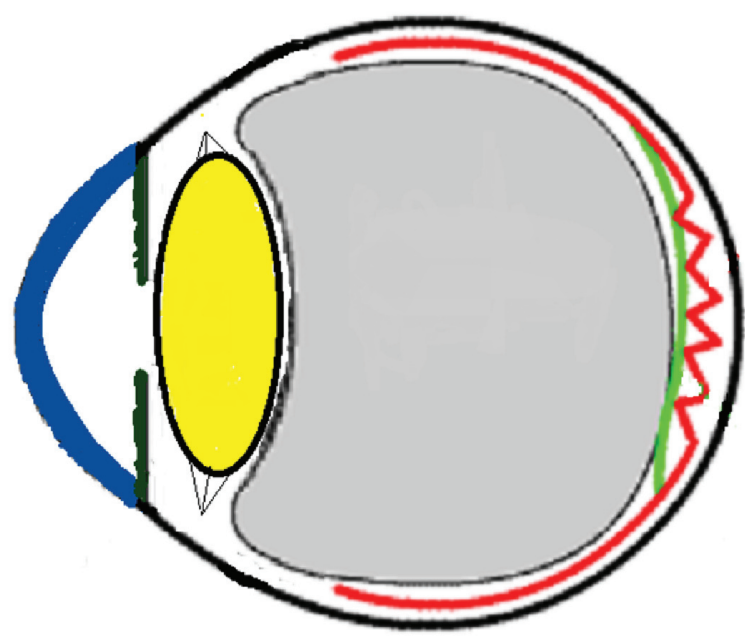

Figure 10 Schematic drawing of an eye with epiretinal membrane. up to $30 \mathrm{mmHg})^{31,32}$ and this places tension on tissues leading to compression of the vitreous against the retinal surface and hence retinal dehiscence in places of retinal lattice or in this case tearing off of the elastic fibrous tissue already under tangential traction at its weakest, thinnest point. Power athletes routinely utilize the Valsalva maneuver during weight-lifting. Valsalva maneuver comprises forcible exhalation against the closed glottis, thereby creating a sudden increase in the intrathoracic or intra-abdominal pressure. Ocular and systemic changes are secondary to the extreme pressure elevations that occur in the intra-abdominal, intrathoracic, intracranial, intraocular, and vascular compartments. The enormous pressures generated lead to elevations in intracranial pressure obstructing venous outflow leading to hemorrhage and elevations in IOP. In one study by Dickerman et al ${ }^{32}$ IOPs were significantly elevated by weight-lifting by $15 \mathrm{mmHg}$

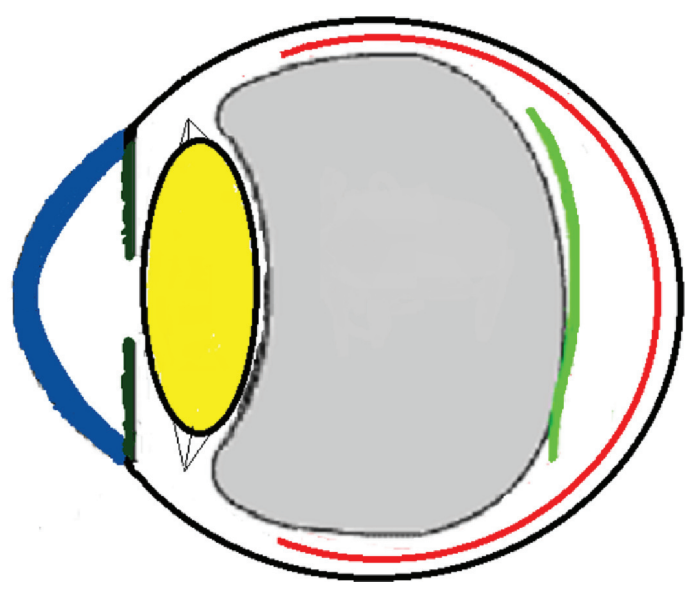

Figure I I Schematic drawing of an adult eye with spontaneous epiretinal membrane (ERM) separation following acute posterior vitreous detachment.

Note: This is the most common mechanism of ERM separation in adults. 


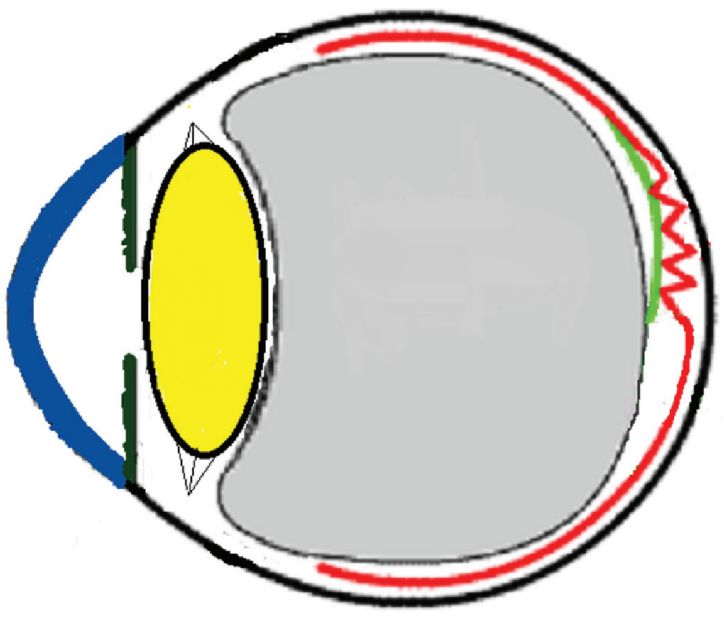

Figure 12 Schematic drawing showing gradual contraction of one edge towards the epicenter in young subjects.

from a mean of 13 to a mean of 28 with one subject's IOP reaching $46 \mathrm{mmHg}$ during maximal contraction. Macdougall et $\mathrm{al}^{33}$ found severe elevations in blood pressure (BP) with mean value of 320/250 $\mathrm{mmHg}$ (BP exceeding 480/350 $\mathrm{mmHg}$ in one subject) and mouth pressures of 30-50 torr during a single maximum lift (normal mouth pressure being 15 torr). This combination of severe elevation in BP and intracranial pressure would have yielded a high incidence of ocular hemorrhage was it not for the dampening effect of high IOP. ERM sites above blood vessels appear to be under focal stress. ERM rupture during weight-lifting was not previously reported in the literature (Table 1). ${ }^{32-42}$

The relation between weight-lifting and ERM separation could be a coincidence with the natural history of ERM taking its course. The current ERM is thought to be primary

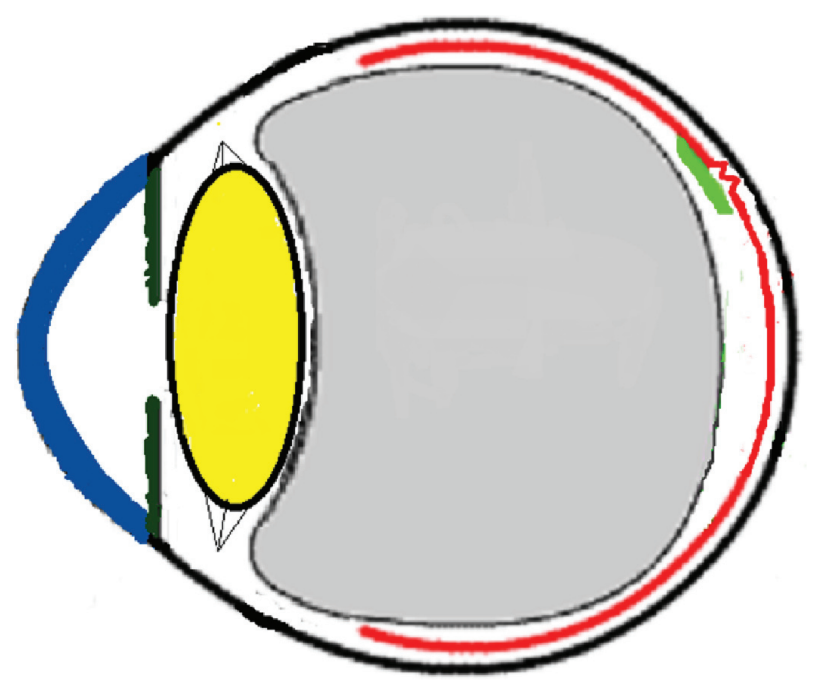

Figure 13 Schematic drawing showing further contraction of one edge resulting in epiretinal membrane release of tension on the fovea.



Figure I4 Schematic drawing showing the severe vitreous pressure from weightlifting putting tension on the thinnest portion of the epiretinal membrane with subsequent rupture of epiretinal membrane.

and not secondary to trauma or inflammatory chorioretinal disorders. Other factors may be involved in ERM separation like rubbing of the eye or minor trauma to the eye, neither of which could be elicited in this case. A table of ocular findings in weight-lifters is enclosed (Table 1).

In conclusion, ERMs in young subjects seems strikingly different from that of those in older individuals; they appear thicker, whiter with high prevalence of myofibroblast cells, hence the contracting forces that stretch the retina. Potential maneuvers that can put stress on ERM surface include severe acute oculopression or rubbing that can raise the IOP acutely and Valsalva maneuvers, hence triggering spontaneous resolution of ERM via rupture in its thinnest meridian with subsequent contraction of the thicker side towards the epicenter.

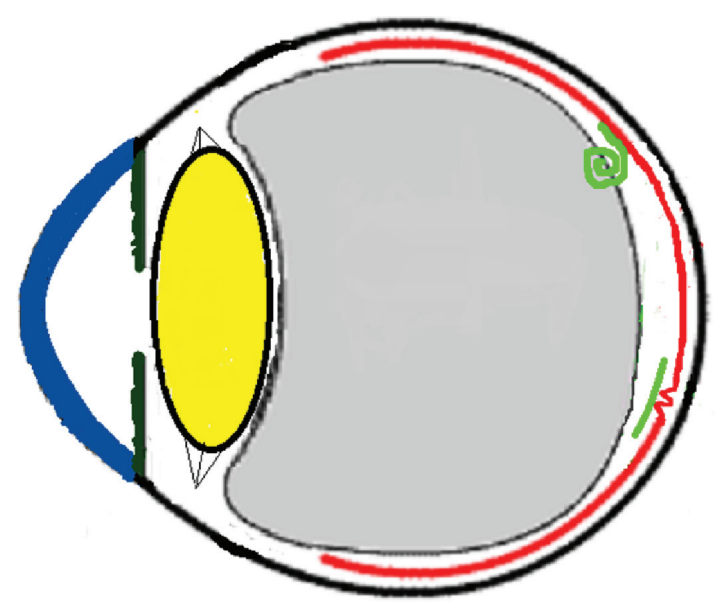

Figure 15 Schematic drawing showing the subsequent retraction and rolling over of the epiretinal membrane (ERM) towards the epicenter nasally following the rupture of ERM. 
Table I Ocular and systemic changes in weight lifters

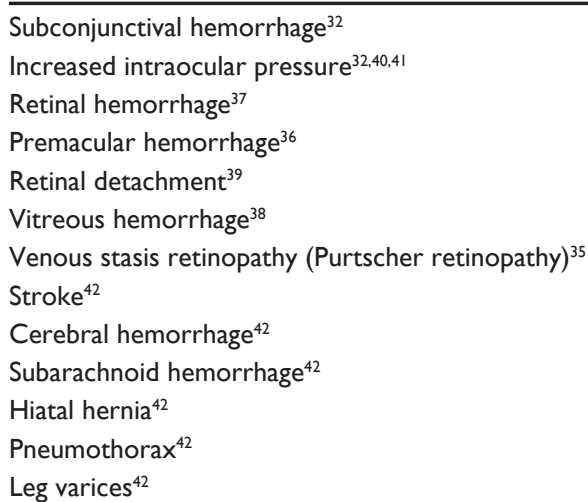

\section{Disclosure}

The authors have no conflicts of interest related to this paper.

\section{References}

1. Khaja HA, McCannel CA, Diehl NN, Mohney BG. Incidence and clinical characteristics of epiretinal membranes in children. Arch Ophthalmol. 2008;126(5):632-636.

2. Benhamou N, Massin P, Spolaore R, Paques M, Gaudric A. Surgical management of epiretinal membrane in young patients. Am J Ophthalmol. 2002;133(3):358-364.

3. Gastaud P, Jammes-Veaux HP, Rouhette H, Durafourg F, Lods F. Indications et résultats de l'éxérèse chirurgicale des membranes épimaculaires congénitales. [Indications and results of surgical removal of "congenital" epimacular membranes]. J Fr Ophtalmol. 1999;22(3): 359-363. French.

4. Smiddy WE, Michels RG, Gilbert HD, Green WR. Clinicopathologic study of idiopathic macular pucker in children and adults. Retina. 1992;12(3):232-236.

5. Banach MJ, Hassan TS, Cox MS, et al. Clinical course and surgical treatment of macular epiretinal membranes in young subjects. Ophthalmology. 2001;108(1):23-26.

6. Kimmel AS, Weingeist TA, Blodi CF, Wells KK. Idiopathic premacular gliosis in children and adults. Am J Ophthalmol. 1989;108(5): 578-581.

7. Wise GN. Congenital preretinal macular fibrosis. Am JOphthalmol. 1975; 79(3):363-365.

8. Greven CM, Slusher MM, Weaver RG. Epiretinal membrane release and posterior vitreous detachment. Ophthalmology. 1988;95(7): 902-905.

9. Kohno RI, Hata Y, Kawahara S, et al. Possible contribution of hyalocytes to idiopathic epiretinal membrane formation and its contraction. Br J Ophthalmol. 2009;93(8):1020-1026.

10. Iannetti L, Accorinti M, Malagola R, et al. Role of the intravitreal growth factors in the pathogenesis of idiopathic epiretinal membrane. Invest Ophthalmol Vis Sci. 2011;52(8):5786-5789.

11. Joshi M, Agrawal S, Christoforidis JB. Inflammatory mechanisms of idiopathic epiretinal membrane formation. Mediators Inflamm. 2013; 2013:192582.

12. Immonen I, Vaheri A, Tommila P, Sirén V. Plasminogen activation in epiretinal membranes. Graefes Arch Clin Exp Ophthalmol. 1996; 234(11):664-669.

13. Webster L, Chignell AH, Limb GA. Predominance of MMP-1 and MMP2 in epiretinal and subretinal membranes of proliferative vitreoretinopathy. Exp Eye Res. 1999;68(1):91-98.

14. Desatnik H, Treister G, Moisseiev J. Spontaneous separation of an idiopathic macular pucker in a young girl. Am J Ophthalmol. 1999; 127(6):729-731.
15. Meyer CH, Rodrigues EB, Mennel S, Schmidt JC, Kroll P. Spontaneous separation of epiretinal membrane in young subjects: personal observations and review of the literature. Graefes Arch Clin Exp Ophthalmol. 2004;242(12):977-985.

16. Garay-Aramburu G, Larrauri-Arana A. Resolucion espontanea de membrana epirretiniana idiopatica en un paciente joven [Spontaneous resolution of an idiopathic epiretinal membrane in a young patient]. Arch Soc Esp Oftalmol. 2005;80(12):741-743. Spanish.

17. Gao H, Salam GA, Chern S. Spontaneous separation of idiopathic epiretinal membrane in a 7-year-old child. J AAPOS. 2007;11(4):393-394.

18. Sachdev N, Gupta V, Gupta A, Singh R. Spontaneous separation of idiopathic epiretinal membrane in a young patient. Int Ophthalmol. 2008;28(4):301-302.

19. Shah PK, Narendran V, Kalpana N. Appearance and spontaneous resolution of macular pucker after triple freeze-thaw cryotherapy for retinoblastoma. J Pediatr Ophthalmol Strabismus. Epub 2009; Jun 25.

20. Mulligan TG, Daily MJ. Spontaneous peeling of an idiopathic epiretinal membrane in a young girl. Arch Ophthalmol. 1992;110(10): $1367-1368$.

21. Schadlu R, Apte RS. Spontaneous resolution of an inflammationassociated epiretinal membrane with previously documented posterior vitreous detachment. Br J Ophthalmol. 2007;91(9):1252-1253.

22. Janknecht P. Spontane Ablösung eines Macular Puckers [Spontaneous resolution of a macular pucker]. Klin Monatsbl Augenheilkd. 1997;211(6):398-399. German.

23. Yang HS, Hong JW, Kim YJ, Kim JG, Joe SG. Characteristics of spontaneous idiopathic epiretinal membrane separation in spectral domain coherence tomography. Retina. 2014;34(10):2079-2087.

24. Nomoto H, Matsumoto C, Arimura E, et al. Quantification of changes in metamorphopsia and retinal contraction in eyes with spontaneous separation of idiopathic epiretinal membrane. Eye (Lond). 2013;27(8):924-930.

25. Sumers KD, Jampol LM, Goldberg MF, Huamonte FU. Spontaneous separation of epiretinal membrane. Arch Ophthalmol. 1980;98(2):318-320.

26. Byer NE. Spontaneous disappearance of early postoperative preretinal traction. Arch Ophthalmol.1973;90(2):133-135.

27. Ray S, Topping T, Young LH. Spontaneous peeling of epiretinal membrane associated with Nd:YAG laser injury. Arch Ophthalmol. 2001;119(1):137-139.

28. Messner KH. Spontaneous separation of preretinal macular fibrosis. Am J Ophthalmol. 1977;83(1):9-11.

29. Morel C, Ameline B, Guiberteau B, Laroche L. Évolution spontanément favorable d'une membrane épirétinienne [Spontaneously favorable course of an epiretinal membrane]. JFr Ophtalmol. 2000;23(9):897-900. French.

30. Enoch JM, Schwartz A, Chang D, Hirose H. Aniseikonia, metamorphopsia and perceived entoptic pattern: some effects of a macular epiretinal membrane, and the subsequent spontaneous separation of the membrane. Ophthalmic Physiol Opt. 1995;15(4):339-343.

31. Mansour AM, Feghali JG, To'mey K, Jaroudi N. Increased intraocular pressure with head-down position. Am J Ophthalmol. 1984;98(1): 114-115.

32. Dickerman RD, Smith GH, Langham-Roof L, McConathy WJ, East JW, Smith AB. Intra-ocular pressure changes during maximal isometric contraction: does this reflect intra-cranial pressure or retinal venous pressure? Neurol Res. 1999;21(3):243-246.

33. Macdougall JD, Tuxen D, Sale DG, Moroz JR, Sutton JR. Arterial blood pressure response to heavy resistance exercise. J Appl Physiol (1985). 1985;58(3):785-790.

34. Mattioli S, De Fazio R, Buiatti E, et al. Physical exertion (lifting) and retinal detachment among people with myopia. Epidemiology. 2008;19(6):868-871.

35. Kocak N, Kaynak S, Kaynak T, Oner HF, Cingil G. Unilateral Purtscher-like retinopathy after weight-lifting. Eur J Ophthalmol. 2003; 13(4):395-397. 
36. Ahmadabadi MN, Karkhaneh R, Mirshahi A, et al. Premacular hemorrhage in Valsalva retinopathy: A study of 21 cases. Iranian Journal of Ophthalmology. 2009;21(3):11-16.

37. Chapman-Davies A, Lazarevic A. Valsalva maculopathy. Clin Exp Optometry. 2002;85(1):42-45.

38. Androudi S, Ahmed M, Brazitikos P, Foster CS. Valsalva retinopathy: diagnostic challenges in a patient with pars-planitis. Acta Ophthalmol Scand. 2005;83(2):256-257.

39. Mattioli S, Curti S, De Fazio R, et al. Occupational lifting tasks and retinal detachment in non-myopics and myopics: Extended analysis of a case-control study. Saf Health Work. 2012;3(1):52-57.
40. Vieira GM, Oliveira HB, de Andrade DT, Bottaro M, Ritch R. Intraocular pressure variation during weight lifting. Arch Ophthalmol. 2006;124(9):1251-1254.

41. Bakke EF, Hisdal J, Semb SO. Intraocular pressure increases in parallel with systemic blood pressure during isometric exercise. Invest Ophthalmol Vis Sci. 2009;50(2):760-764.

42. Dickerman RD, McConathy WJ, Smith GH, East JW, Rudder L. Middle cerebral artery blood flow velocity in elite power athletes during maximal weight-lifting. Neurol Res. 2000;22(4):337-340.
Clinical Ophthalmology

\section{Publish your work in this journal}

Clinical Ophthalmology is an international, peer-reviewed journal covering all subspecialties within ophthalmology. Key topics include: Optometry; Visual science; Pharmacology and drug therapy in eye diseases; Basic Sciences; Primary and Secondary eye care; Patient Safety and Quality of Care Improvements. This journal is indexed on

\section{Dovepress}

PubMed Central and CAS, and is the official journal of The Society of Clinical Ophthalmology (SCO). The manuscript management system is completely online and includes a very quick and fair peer-review system, which is all easy to use. Visit http://www.dovepress.com/ testimonials.php to read real quotes from published authors. 